
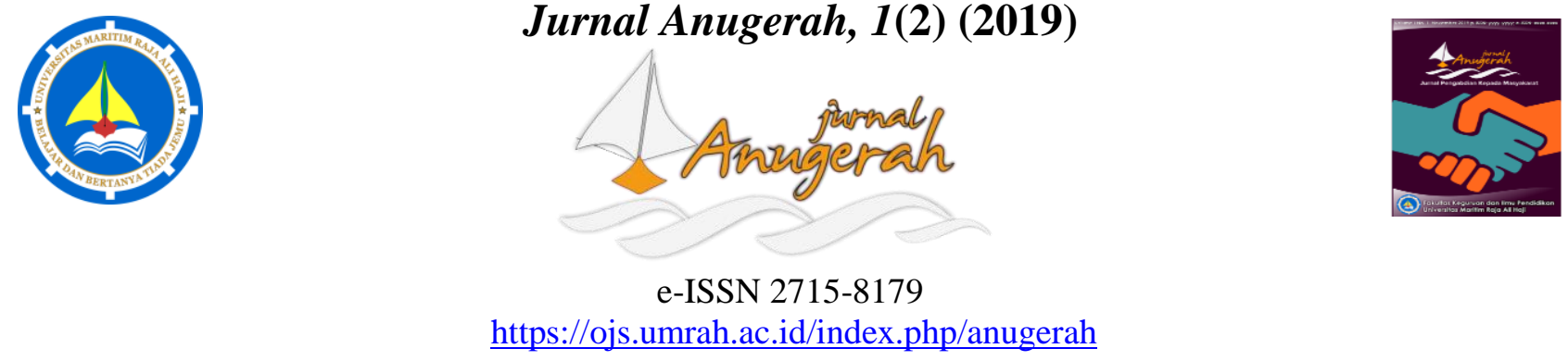

https://ojs.umrah.ac.id/index.php/anugerah

\title{
Pembekalan Pra-OSN Menggunakan Soal-Soal Problem Solving Berbasis Representasi Multimodus bagi Siswa SMP
}

\author{
Metta Liana $^{1^{*}}$, Dios Sarkity ${ }^{2}$, Mariyanti Elvi ${ }^{3}$, Dina Fitriyah ${ }^{4}$ \\ 1, 2,3,4 Universitas Maritim Raja Ali Haji, Tanjungpinang, Provinsi Kepulauan Riau 29115, Indonesia \\ e-mail:*mettaliana@umrah.ac.id
}

Pengiriman: 1 Desember 2019; Diterima: 23 Desember 2019; Publikasi: 30 Desember 2019

DOI: https://doi.org/10.31629/anugerah.v1i2.1784

\begin{abstract}
Abstrak
Salah satu upaya pemerintah dalam meningkatkan mutu pendidikan bagi peserta didik yang memiliki kecerdasan dan bakat istimewa di wilayah Indonesia adalah melalui OSN.Dalam kenyataanya peraih medali OSN rata-rata di dominasi oleh siswadari pulau Jawa. Perolehan medali OSN yang tidak merata mengindikasikan kurang optimalnya persiapan siswa dari daerah lain. Permasalahan yang sama juga ditemui di sekolah menengah di Tanjungpinang. Pihak sekolah masih menitikberatkan materi pada tingkat hafalan saja dan tidak menampilkan keterampilan abad 21 dalam prosespembelajaran. Tujuan dari kegiatan PkM ini adalah untuk mempersiapkan siswa SMP N 4 di Tanjungpinang yang akan mengikuti OSN tahun 2020 dengan pembelajaran yang menggunakan soal-soal problem solving berbasis representasi multimodus terkhusus materi IPA (fisika). Hasil kegiatan PkM ini adalah: (1) Adanya pemahaman konsep IPA (fisika) yang lebih tinggi dengan menggunakan soal-soal problem solving berbasis representasi multimodus bagi siswa. (2) Adanya motivasi yang tinggi dari siswa untuk belajar mandiri dalam mempersiapkan OSN 2020 dan motivasi untuk menaklukan materi IPA (fisika) lainnya. (3) Adanya permintaan dari sekolah agar pembekalan Pra-OSN bisa berkelanjutan dan siswa yang diikutkan bisa lebih banyak.
\end{abstract}

Kata kunci: problem solving; OSN; representasi multimodus

\begin{abstract}
One of the government's efforts to improve the quality of education for students who have special intelligence and talent in Indonesia is through OSN. In fact, the champions ofthe competition were dominated by students from Java. This case indicates that the students' preparations from other region are not optimal. The same problem was also found at junior high school in Tanjungpinang.The school still emphasizes the material at the level of memorization, and does not display 21 st century skills in learning. The purpose of this PkM is to prepare students of SMP N 4 in Tanjungpinang who will take part in the OSN in 2020. They are thaught by using problem solving based multimodal representation for physics materials. The results of this PkM are: (1) Students' understanding of the concept of science (physics) by using problem solving based multimodal representation. (2) Students' motivation to learn independently for preparing OSN 2020 and mastery other physic material. (3) Demand for continue this program and involve more students than before.
\end{abstract}

Keywords: Problem solving; OSN; multimodal representation

\section{Pendahuluan}

Era tantangan abad 21 membuat negara di dunia berlomba-lomba untuk meningkatkan daya saingnya agar mampu beradaptasi dengan lingkungan baru serta sanggup pula menjadi komunitas terbaik yang diperhitungkan keberadaannya dalam percaturan pergaulan dunia. Salah satu upaya Indonesia untuk meningkatkan daya saing dunia adalah dengan adanya inovasi yang dilakukan dalam rangka meningkatkan 
mutu pendidikan, yaitu dengan mempersiapkan peserta didik untuk memiliki kemampuan berpikir tingkat tinggi sebagai salah satu contohnya (BNSP, 2010). Pemerintah melakukan penjaminan mutu pendidikan serta pembinaan berkelanjutan kepada peserta didik yang memiliki kecerdasan atau bakat istimewa untuk mencapai prestasi puncak di bidang pengetahuan, teknologi, seni dan atau olahraga pada tingkat satuan pendidikan, kabupaten/kota, provinsi, nasional dan internasional (BPK, 2010). Berbagai usaha telah dilakukan pemerintah dalam menjamin mutu pendidikan.

Usaha peningkatan mutu pendidikan yang dilakukan salah satunyaadalah dengan mengembangkan OSNagar peserta didik mampu berpikir tingkat tinggi (kritis, kreatif, problem solving, kolaboratif dan inovatif). Selain itu, OSN merupakan wadah siswa mengimplementasikan Penguatan Pendidikan Karakter (PPK) melalui sains dalam upaya mengembangkan wahana kompetisi bagi siswa SMP/MTS Negeri atau Swasta yang sederajat di seluruh Indonesia di bidang Matematika, IPA dan IPS. Hadirnya OSN diharapkan mampu meningkatkan atmosfer kompetisi secara sehat dan jujur antar sekolah, sehingga sekolah berlombalomba mengembangkan program peningkatan mutu pembelajaran dalam mata pelajaran Matematika, IPA, dan IPS dan mengantarkan para siswa Indonesia mencintai sains (Kemdikbud, 2019).

Sejak OSN SMP dilaksanakan, banyak sekolah yang telah termotivasi untuk mengembangkan program peningkatan mutu pembelajaran di bidang Matematika, IPA, dan IPS. Hal tersebut mengindikasi bahwa dampak positif dari kegiatan OSN sudah terlihat dan menjadi gerakan nasional untuk mengembangkan pendidikan sains mulai dari skala sekolah, hingga level nasional. Akan tetapi dalam kenyataannya rata-rata perolehan medali OSN tingkat Nasional masih di dominasi oleh peserta didik dari pulau Jawa. Daftar provinsi yang siswanya mendapat medali OSN IPA tahun 2019 sebanyak 30 siswa disajikan pada Tabel 1.

Tabel 1.

Perolehan Medali OSN IPA Tahun 2019

\begin{tabular}{lccc}
\hline Provinsi & $\begin{array}{c}\text { Medali } \\
\text { Emas }\end{array}$ & $\begin{array}{c}\text { Medali } \\
\text { Perak }\end{array}$ & Medali Perunggu \\
\hline DKI Jakarta & 3 & 1 & 1 \\
Banten & 1 & & \\
Riau & 1 & & 3 \\
Jawa Barat & & 4 & 2 \\
Jawa Tengah & 1 & 1 & 4 \\
Jawa Timur & 1 & & \\
NTB & 1 & 1 \\
Kalimantan Timur & 1 & 1 \\
Sumatera Utara & & & 1 \\
Lampung & & & 1 \\
Sulawesi Selatan & & & 1 \\
Sulawesi Tengah & & & \\
D.I. Yogyakarta & & & \\
Kalimantan Barat & & & \\
\hline
\end{tabular}

Sumber: Kemdikbud, 2019

Berdasarkan data Tabel 1, perolehan medali OSN sangat didominasi dari pulau Jawa, sekitar 4 medali emas, 7 medali perak dan 11 medali perunggu. Sedangkan pulau Sumatera hanya memperoleh 1 medali emas, 1 medali perak dan 1 medali perunggu dan terlihat belum adanya sumbangan medali dari Provinsi Kepulauan Riau pada tahun 2019 di bidang IPA SMP. Dari paparan data tersebut, perlu adanya suatu dukungan bagi sekolah-sekolah di daerah, khususnya Tanjungpinang untuk meningkatkan mutu pembekalan bagi siswa yang akan mengikuti OSN di tahun berikutnya agar tujuan OSN dapat tersebar merata di 34 provinsi. Dukungan tersebut bisa berupa pemberian informasi terkait skema OSN, pelatihan terstruktur dan berkelanjutan agar 
dapat membantu sekolah dalam rangka akselarasi program peningkatan mutu pendidikan sains. Sekolah memberikan kontribusi terbesar bagi peserta didik dalam berprestasi sesuai minat dan bakat mereka baik itu matematika maupun sains sesuai dengan fase awal perkembangan mereka (Steegh, Höffler, Keller, \& Parchmann, 2019). Dalam hal ini sekolah berperan sebagai fasilitator peserta didik. Dari permasalahan tersebut perlu dilakukan pelatihan dalam bentuk pembekalan pra-OSN kepada siswa SMP di Tanjungpinang dalam mempersiapkan diri mengikuti OSN berikutnya.

Pembekalan OSN sejatinya sudah ada di tiap sekolah, karena tiap sekolah sudah memiliki guru-guru pembina olimpiade di masing-masing bidang. Namun, pembekalam tersebut belum optimal dikarenakan beberapa alasan.Pertama, dilihat dari frekuensi belajar siswa yang hanya terfokus di waktu-waktu mendekati seleksi OSN saja, tidak dipersiapkan dari awal seleksi sekolah. Kedua, guru pembina olimpiade pada satu sekolah terdiri dari satu atau dua bidang saja, padahal untuk OSN SMP itu meliputi bidang Fisika, Biologi dan Kimia serta ada kalanya guru yang mengajar bukan dari bidang mereka yang sebenarnya. Ketiga, guru-guru di sekolah lebih menitikberatkan materi pada tingkat hapalan rumus saja, tidak menekankan pada keterampilan abad 21 yang harus dikuasai siswa. Siswa tidak dibiasakan dalam menyelesaikan soal menggunakan pendekatan pemecahan masalah (problem solving) dengan penjabaran representasi multimodus dimana penafsiran kalimat bisa ditampilkan dalam bentuk gambar, diagram dan persamaan matematis.

Problem solving merupakan elemen penting dalam pembelajaran,siswa belajar untuk berpikir tentang fenomena secara kualitatifdengan menggunakan berbagai representasi (misalnya: free-body diagram and energy bar charts) (Docktor, Strand, Mestre, \& Ross, 2015). Representasi dibutuhkan dalam setiap penyelesaian soal IPA. Multi representasi adalah model yang mempresentasi ulang konsep yang sama dalam beberapa format yang berbeda-beda. Beberapa bentuk representasi dalam IPA bisa berupa kata, gambar, diagram, grafik, simulasi komputer, persamaan matematika dan sebagainya (Irwandani, 2014). Setiap siswa memiliki pemahaman representasi modus yang berbeda dalam menghadapi kesulitan saat menstransfer keterampilan pemecahan masalah yang dihadapi ke semua representasi (Nguyen, Gire, \& Rebello, 2010). Kemampuan memecahkan masalah dibangun oleh konsep-konsep materi dan cara/langkah untuk memecahkan masalahnya. Dalam hal ini, konsep-konsep materi berperan penting dalam memecahkan masalah. Bila siswa memiliki konsep yang kaya akan representasi, maka kemampuan pemecahan masalah akan baik pula, tidak hanya sebatas mengingat atau recall task.

Beberapa tahun terakhir, sudah banyak publikasi terkait pelatihan OSN ke pada siswa dan guru dalam peningkatan pemahaman konsep dan pemahaman tentang pelaksanan OSN (Ariyanti, Rahajeng, \& Sumadji, 2019; Muliani, Noviati, \& Fajriani, 2018; Rachmawati, 2014; Wiyoko \& Avana, 2019). Serta publikasi yang menyatakan OSN dapat menumbuhkan bakat dan minat peserta didik dalam bidang sains (Marlina, Puspaningrum, \& Hamdani, 2017). Pada kegiatan PkM ini lebih memfokuskan pada keterampilan abad 21 yaitu problem solving di pemaparan materi dan pembahasan soal.Pelatihan pra OSN sains perlu diberikan kepada siswa menggunakan pendekatan pemecahan masalah (problem solving) menggunakan representasi multimodus pada tiap-tiap soal. Sesuai dengan tujuan OSN oleh Kemendikbud maka pelatihan ini lebih menekankan pada aspek keterampilan abad 21, terkhususnya problem solving. Siswa diminta tidak hanya hapal rumus saja tetapi paham konsep sehingga apapun bentuk soal nantinya bisa diselesaikan dengan baik. 


\section{Metode}

Pengabdian kepada masyarakat $(\mathrm{PkM})$ ini dilaksanakan menggunakan metode pendidikan masyarakat dimana dilakukan pelatihan pada siswa SMP untuk mendapatkan pemahaman dan bekal dalam mengikuti suatu kompetisi tingkat SMP sederajat yang dikenal dengan OSN. Pelatihan ini menekankan pada kemampuan pemecahan masalah (problem solving) berbasis representaasi multimodus dalam menyelesaikan soal-soal IPA berstandar OSN. Pada tahapan pra kegiatan, tim PkM melakukan survey pada sekolah di Tanjungpinang yang memiliki akreditasi A (unggul). Pilihan tim PkM jatuh pada SMP N 4 Tanjungpinang, kemudian tim PkM mewawancara kepala dan wakil kepala SMP N 4 Tanjungpinang terkait pelaksanaan pelatihan Pra OSN di sekolah tersebut. Pihak mitra menyambut baik tawaran pelatihan pra OSN bagi siswa-siswi mereka karena diharapkan dapat memberikan kontribusi yang besar bagi siswa dan guru.Waktu pelaksanaan PkM ini adalah 5 (lima) minggu di bulan November. PkM ini dianalisis menggunakan metode deskriptif untuk melihat pemahaman siswa terkait materi yang disampaikan melalui tes berupa soal-soal dengan penyelesaian problem solving yang menggunakan representasi multimodusdan ketertarikan siswa dalam pelatihan dengan menyebarkan angket yang berisi 10 aspek/deskripsi yang tergabung pada 4 komponen yaitu pemahaman materi, motivasi untuk belajar, alokasi waktu pelatihan, dan pemapar materi.Tes akhir yang diberikanjuga berguna sebagai salah satu instrumen dalam menentukan siswa mana nantinya yang akan ditunjuk oleh pihak sekolah untuk mengikuti OSN 2020.

TIM PkM ini terdiri dari 4 orang dosen yang memberikan materi pada kegiatan pelatihan serta 4 orang mahasiswa yang bertugas dalam memastikan teknis kegiatan berjalan lancar seperti mengkoordinir siswa, memastikan ruangan pelatihan, pengawasan saat pengisian angket dan pelaksanaan tes, serta pengurusan surat yang berkaitan dengan pelatihan ke pihak mitra. Mahasiswa yang terlibat merupakan mahasiswa yang sedang melakukan kegiatan PPL di lokasi Mitra. Siswa-siswi yang terlibat dalam pelatihan berjumlah 15 orang yang merupakan perwakilan siswa berprestasi dari tiap-tiap kelas. Siswa yang ikut pelatihan merupakan siswa kelas 7 dan siswa kelas 8 .

\section{Hasil dan Pembahasan}

Kegiatan PkM di SMP N 4 Tanjungpinang dilaksanakan selama 5 minggu di setiap hari Sabtu pada pukul 13.00 WIB - 15.00 WIB. Pertemuan pertama diisi dengan acara pembukaan pelatihan yang dihadiri oleh waka humas dan waka kesiswaan yang mewakili kepala sekolah yang sedang dinas luar, 6 orang guru bidang studi yang juga berperan sebagai guru pembina olimpiade, mahasiswa PPL dan siswa yang akan mengikuti pelatihan. Pada acara pembukaan pelatihan, waka siswa memberikan kata sambutan berupa respon positif dari sekolah terkait kegiatan yang akan dilaksanakan. Dari pihak tim PkM juga menyampaikan ucapan terima kasih kepada mitra untuk terlaksananya kegiatan. Setelah itu,tim PkM juga menyampaikan skema pelatihan PraOSN dan target yang bisa dicapai, penyerahan modul pelatihan dan foto bersama. Berikut ini disajikan dokumentasi foto selama kegiatan PkM: 


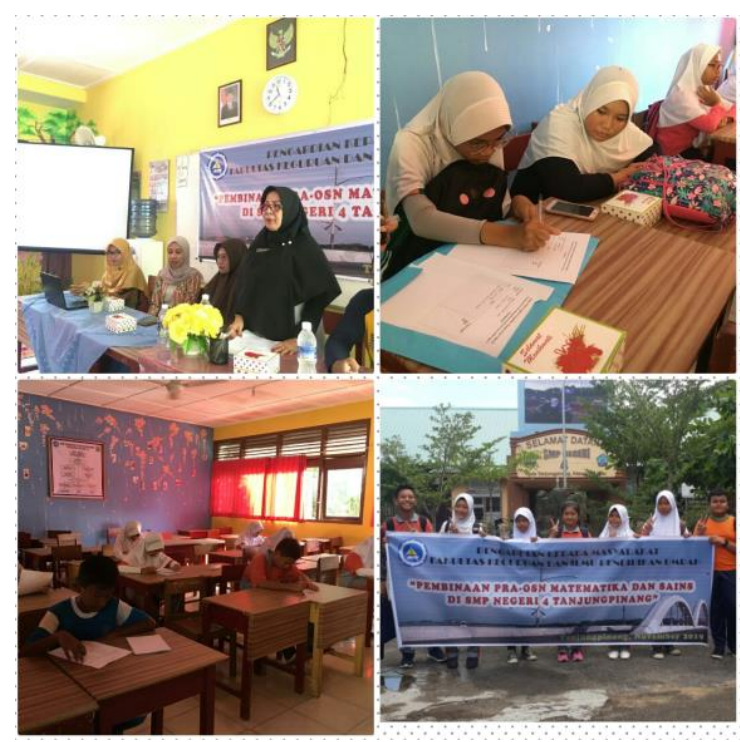

Gambar 1. Dokumentasi pelaksanaan PkM di SMP N 4 Tanjungpinang

Gambar 1 memperlihatkan dokumentasi kegiatan PkM selama satu bulan (mulai dari pembukaan, pelaksanaan pembekalan pra-OSN, pengisian angket dan tes, serta foto bersama di akhir pelatihan).

Pertemuan kedua, kegiatan pelatihan diisi dengan perkenalan dengan siswa untuk membangun bonding agar suasana pembelajaran santai tapi bermakna. Tidak lupa dosen memberikan motivasi ke siswa tentang seleksi, pelaksanaan dari OSN yang akan mereka ikuti nantinya. Kemudian dilanjutkan dengan pemaparan konsep pengukuran dan besaran-besaran fisika, pada pemaparan materi juga diberi contoh soal yang penyelesaiannya menggunakan pendekatan pemecahan masalah yang berbasis representasi multimodus. Langkah-langkah pada prosedur pemecahan masalah yang digunakan ada empat (Van Heuvelen \& Zou, 2001):

1. Mengambar dan menerjemahkan masalah yang ditanyakan. Mendeskripsikan dan menggambarkan keadaan yang terdapat dalam soal, memasukkan semua informasi yang diketahui dari soal tersebut dan memilih sistem dari setiap objek serta membuat daftar interaksi antara objek dan sistem.

2. Menyederhanakan permasalahan tersebut.

3. Menggambarkan bentuk fisisnya. Bentuk fisis yang akan digambarkan disesuaikan dengan materi dan gambaran fisis apa yang memungkinkan untuk materi tersebut

4. Menyelesaikan permasalahan secara matematis

Prosedur pemecahan masalah disertai berbasis multimodus. Multimodus didefinisikan sebagai penggabungan modus representasi yang berbeda dalam merepresentasikan penalaran ilmiah dan temuannya (Prain \& Waldrip, 2006). Pada Tabel 2 berikut ditampilakan contoh representasi modus pada materi fisika gerak harmonik sederhana. 
JURNAL ANUGERAH. Desember 2019; I(2): 59 - 69

e-ISSN 2715-8179

Tabel 2.

Contoh Representasi Modus pada Materi Fisika

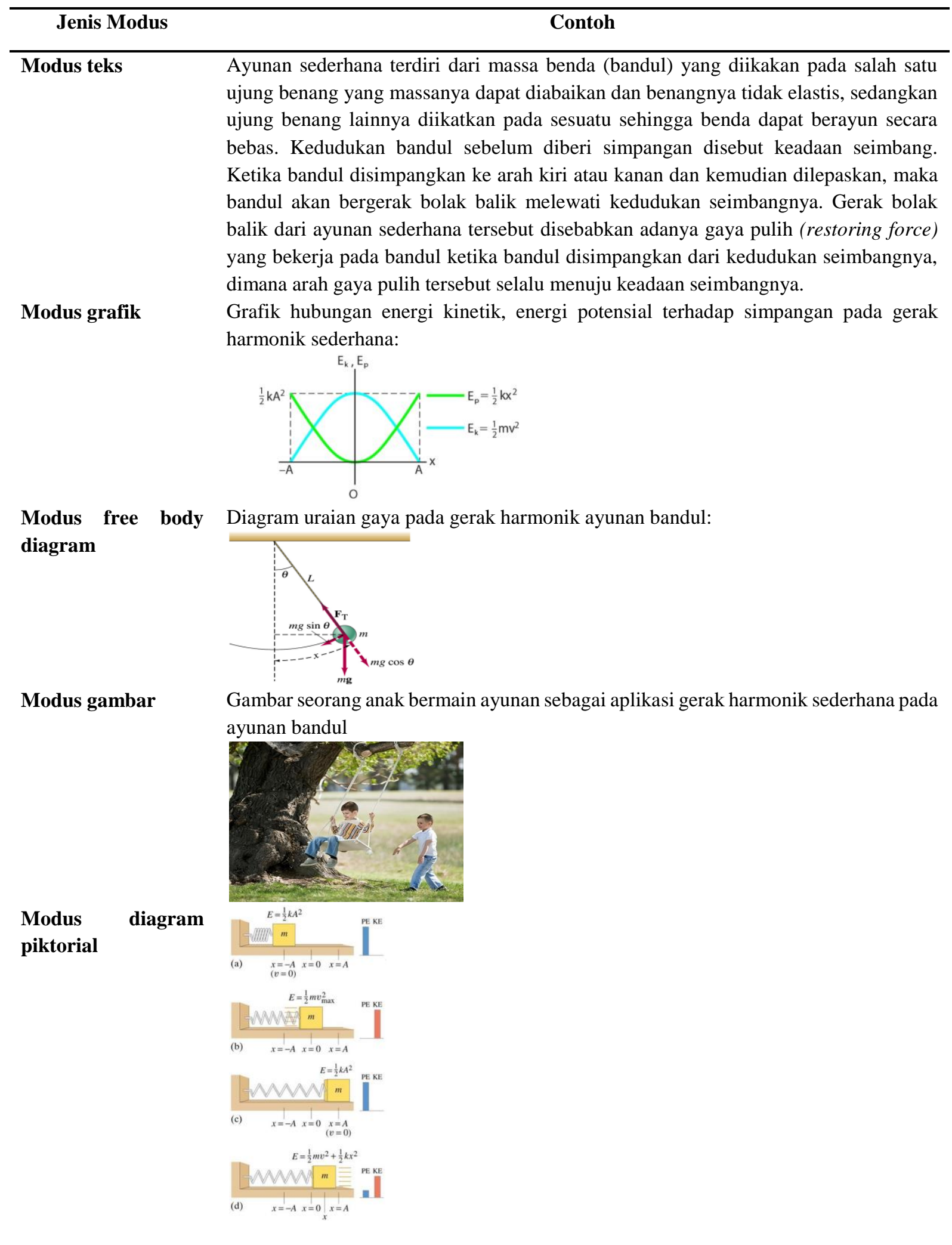


Pemaparan materi dengan membangun konsep pada siswa dilanjutkan dengan pembahasan soal, siswa sedikit agak kebingungan karena belum terbiasa. Kemudian dilakukan pembahasan soal kedua sesuai skema yang telah direncanakan agar siswa lebih paham dalam menterjemahkan soal dan menuliskan representasi yang bisa ditafsirkan dari soal tersebut. Pada soal ketiga siswa diminta mengerjakan soal sendiri sesuai tahapan pemecahan masalah menggunakan representasi verbal teks dan representasi gambar.Pembahasan soal ini dengan pendampingan langsung oleh dosen ke masing-masing siswa. Dari empat tahap pemecahan masalah yang ada siswa baru terbiasa menggunakan tahapan ke-1 dan ke-3.Untuk membiasakan siswa, di akhir pertemuan, siswa diminta untuk menyelesaikan soal-soal yang ada pada modul yang diberikan di rumah sesuai tahapan saat latihan agarmahir. Pada Gambar 2 berikut ditampilkan contoh soal yang digunakan saat pelatihan.

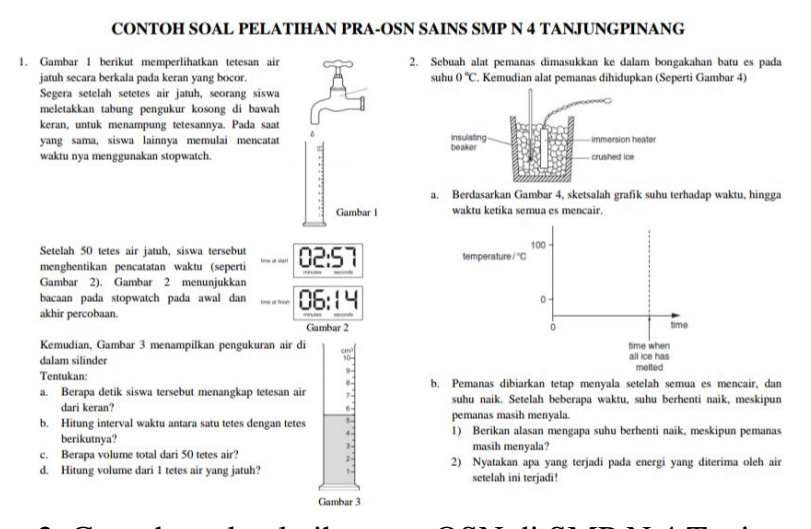

Gambar 2. Contoh soal pelatihan pra OSN di SMP N 4 Tanjungpinang

Pertemuan ketiga, kegiatan pelatihan diisi dengan pemaparan konsep suhu dan pemuaian zat. Materi yang diberikan juga disertai representasi modus. Kemudian siswa diajarkan lagi penyelesaian soal menggunakan pendekatan pemecahan masalah menggunakan representasi verbal teks ke representasi grafik. Siswa sudah cukup mahir dalam menggunakan 3 prosedur pemecahan masalah. Siswa sudah naik satu tingkat. Siswa sudah bisa menyelesaikan prosedur kedua yaitu menyederhanakan permasalahan tersebut (di lihat dari salah satu soal kalor yang menyebutkan suhu lingkungan di abaikan). Pada pertemuan keempat, kegiatan pelatihan sama dengan pertemuan sebelumnya, tetapi pada materi kalor dan perpindahan kalor. Di pertemuan ini siswa sudah cukup mahir menggunakan 4 langkah pemecahan masalah dalam pembahasan soal serta representasi modus yang digunakan sudah pada representasi verbal teks ke representasi gambar dan representasi persamaan matematis. Gambar 3 berikut memperlihatkan salah satu pengerjaan siswa pada soal kalor.

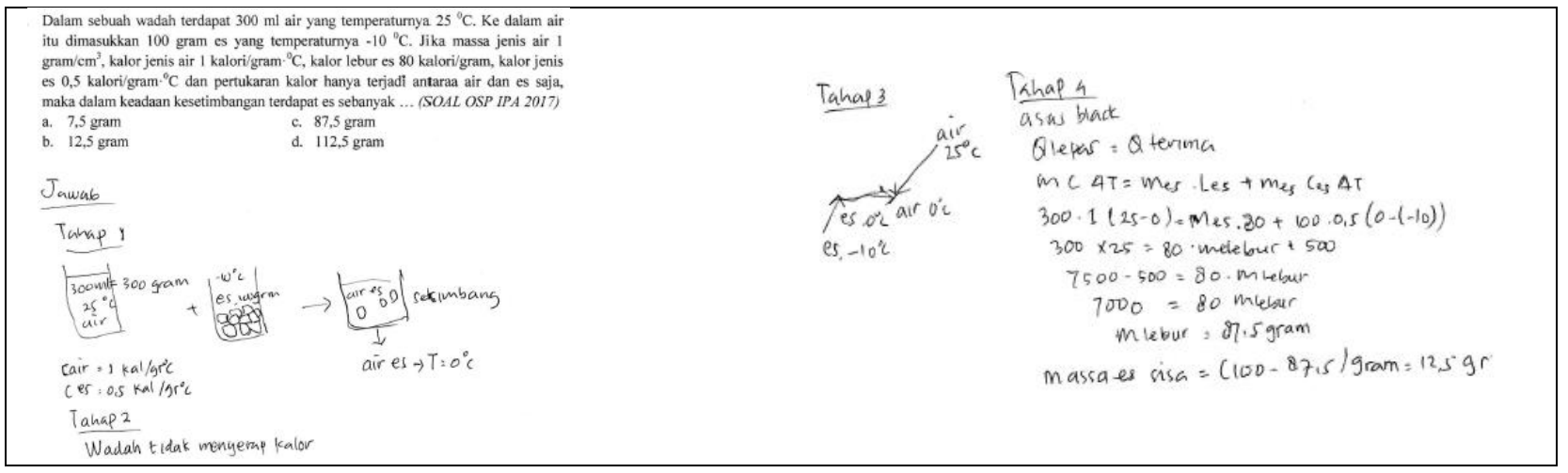

Gambar 3. Contoh jawaban siswa menggunakan tahapan Problem Solving pada Materi Kalor

Berdasarkan Gambar 3, terlihat siswa sudah menjawab sesuai tahapan problem solving. Pada tahapan 1, siswa sudah mendeskripsikan dan menggambarkan keadaan yang terdapat dalam soal yaitu percampuran antara es dan air dimana suhu setimbang $0{ }^{\circ} \mathrm{C}$ menandakan tidak semua es mencair (deskripsi yang disampaikan 
berupa mudus gambar). Pada tahapan 2, menyederhanakan permasalahan, ini terlihat dari jawaban wadah tidak menyerap kalor karena dari soal dinyatakan pertukaran kalor hanya terjadi pada air dan es (modus teks). Kemudian pada tahap 3, menggambarkan bentuk fisis, terlihat pada jawaban siswa menuliskan grafik perubahan wujud dan suhu (modus grafik). Tahapan terakhir, menyelesaikan permasalahan secara matematis, terlihat dari jawaban siswa dalam menentukan massa es sisa setelah setimbang (modus persamaan matematis).

Pada pertemuan kelima, kegiatan pelatihan diisi dengan pemaparan konsep usaha dan energi, serta pembahasan soal. Pemahaman siswa sudah lebih baik dibanding pertemuan sebelumnya dalam penyelesaian soal dengan berbagai representasi modus yang berbeda-beda menggunakan 4 langkah pemecahan masalah. Hanya saja siswa agak kesulitan dalam merepresentasikan modus grafik ke modus persamaan atau modus teks. Salah satunya contohnya siswa kesulitan dalam menginterprestasikan grafik hubungan gaya dengan perpindahan untuk menentukan besar usaha. Kesulitan ini terjadi karena ketidaktauan terhadap suatu daerah dibawah kurva (Maries \& Singh, 2013). Masalah ini dapat diatasi dengan latihan soal yang rutin dan diiringi pemahaman konsep yang lebih baik pada materi fisika yang lebih mendalam. Setelah pelatihan ini selesai, tim PkM memberikan tes dan angket yang terkait pada pelatihan di hari berikutnya, kegiatan ini dilaksanakan oleh mahasiswa, kemudian menyerahkannya kepada Dosen.

Setelah menerima hasil jawaban tes siswa kemudian dianalisis sesuai dengan tahapan pemecahan masalah yang sudah dilatihkan agar terlihat pencapaian tujuan pengabdian masyarakat. Hasil capaian rata-rata siswa dapat dilihat pada Gambar 4.

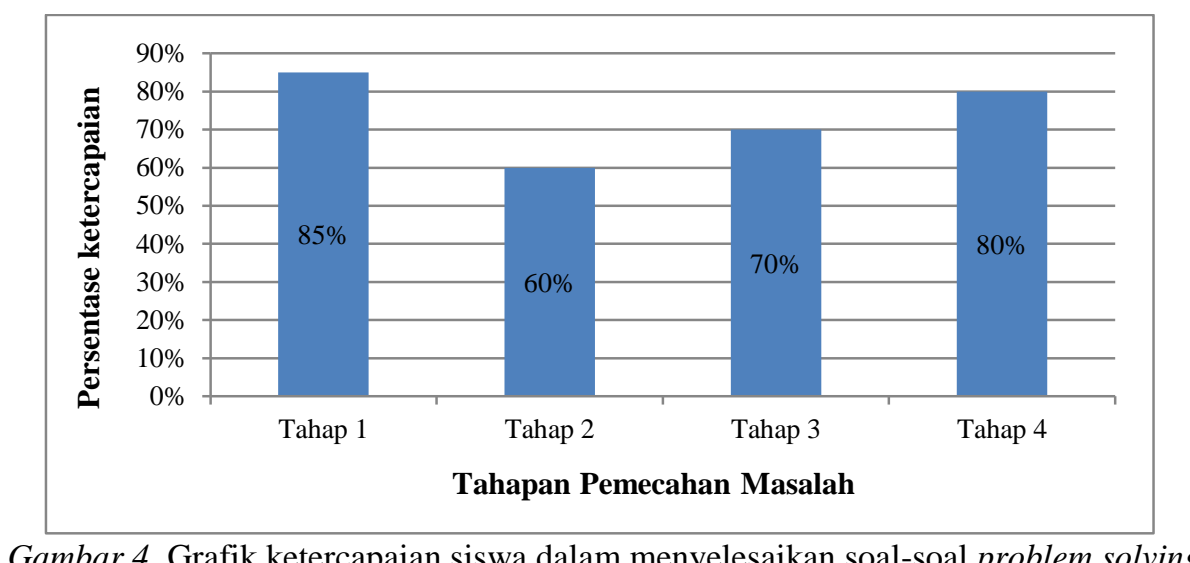

Gambar 4. Grafik ketercapaian siswa dalam menyelesaikan soal-soal problem solving

Berdasarkan grafik ketercapaian siswa dalam menyelesaikan soal-soal problem solving pada Gambar 3 dapat ditarik kesimpulan bahwa siswa yang mengikuti pelatihan pra-OSNcukup baik dalam menyelesaikan tes. Tiap soal yang diberikan mengukur 4 tahapan pemecahan masalah, tahapan pemecahan masalah yang paling dikuasai siswa yaitu tahapan 1 (menggambarkan dan menerjemahkan masalah yang ditanyakan) dengan angka ketercapaian 85\% dimana mengindikasikan siswa bisa merepresentasikan berbagai modus, baik itu verbal teks, gambar, dan grafik. Sedangkan tahapan yang paling rendah yaitu tahapan 2 (menyederhanakan permasalahan tersebut), tahapan ini rendah karena siswa seringkali mengabaikan kondisi-kondisi tertentu pada soal yang sebenarnya cukup krusial. Perlunya perbaikan kedepannya bagi siswa dalam melatihkan tahapan ini. Pendekatan problem solving merupakan salah satu pendekatan pembelajaran keterampilan abad 21 yang menunjang pada soal-soal olimpiade (Ekmekci \& Sahin, 2018).

Selain dari tes, pada evaluasi pelatihan diberikan juga angket respon siswa berupa 10 aspek/deskripsi yang tergabung pada 4 komponen yaitu pemahaman materi, motivasi untuk belajar, alokasi waktu pelatihan, dan pemapar materi, Angket yang diberikan menggunakan skala likert. Aspek/deskripsi angket siswa ditampilkan pada Tabel 3 berikut. 
Tabel 3.

Analisis Persentase Respon Siswa terhadap Pelatihan Pra-OSN

\begin{tabular}{|c|c|c|c|c|}
\hline No. & Aspek/Deskripsi & Jumlah & $\begin{array}{l}\text { Jumlah } \\
\text { Total }\end{array}$ & Persentase \\
\hline & Pemahaman materi & & & \\
\hline 1. & $\begin{array}{l}\text { Saya bisa memahami konsep fisika lebih baik setelah mengikuti } \\
\text { pelatihan Pra-OSN }\end{array}$ & 57 & 60 & $95 \%$ \\
\hline 2. & $\begin{array}{l}\text { Saya lebih terampil dalam memahami masalah pada setiap soal-soal } \\
\text { olimpiade melalui pelatihan Pra-OSN }\end{array}$ & 56 & 60 & $93 \%$ \\
\hline \multirow[t]{3}{*}{3.} & $\begin{array}{l}\text { Saya lebih mengerti langkah-langkah apa yang harus dilakukan } \\
\text { untuk menyelesaikan masalah pada setiap soal olimpiade melalui } \\
\text { pelatihan pra-OSN }\end{array}$ & 58 & 60 & $97 \%$ \\
\hline & Persentase rata-rata komponen pemahaman materi & & & $95 \%$ \\
\hline & Motivasi untuk belajar & & & \\
\hline 1. & $\begin{array}{l}\text { Saya lebih termotivasi untuk belajar mandiri dalam mempersiapkan } \\
\text { diri mengikuti olimpiade setelah dibekali pemahaman konsep dan } \\
\text { diberikan bimbingan dalam menyelesaian masalah pada setiap soal } \\
\text { olimpiade melalui pelatihan pra-OSN }\end{array}$ & 55 & 60 & $91 \%$ \\
\hline 2. & $\begin{array}{l}\text { Saya semakin tertarik dan bersemangat untuk mengikuti kegiatan } \\
\text { olimpiade setelah mengikuti pelatihan Pra-OSN }\end{array}$ & 57 & 60 & $95 \%$ \\
\hline \multirow[t]{3}{*}{3.} & $\begin{array}{l}\text { Saya merasa lebih siap untuk bertanding mengikuti olimpiade } \\
\text { setelah mengikuti pelatihan pra-OSN }\end{array}$ & 56 & 60 & $93 \%$ \\
\hline & Persentase rata-rata untuk komponen motivasi belajar & & & $93 \%$ \\
\hline & Alokasi waktu pelatihan & & & \\
\hline \multirow[t]{3}{*}{1.} & $\begin{array}{l}\text { Alokasi waktu yang digunakan untuk pelatihan Pra-OSN sangat } \\
\text { efektif untuk memberikan bimbingan dalam menyelesaikan soal } \\
\text { olimpiade berdasarkan materi yang dipelajari pada setiap } \\
\text { pertemuan }\end{array}$ & 42 & 60 & $70 \%$ \\
\hline & Persentase rata-rata untuk komponen alokasi waktu & & & $70 \%$ \\
\hline & Pemapar materi & & & \\
\hline 1. & $\begin{array}{l}\text { Pengajar yang memberikan pelatihan pra-OSN matematika dan } \\
\text { sains mampu memberikan pemahaman konsep secara baik } \\
\text { mengenai materi-materi yag diujikan dalam olimpiade }\end{array}$ & 59 & 60 & $98 \%$ \\
\hline 2. & $\begin{array}{l}\text { Pengajar yang memberikan pelatihan pra-OSN matematika dan } \\
\text { sains mampu memberikan bimbingan secara baik dalam } \\
\text { menyelesaikan masalah pada soal-soal olimpiade }\end{array}$ & 59 & 60 & $98 \%$ \\
\hline \multirow[t]{2}{*}{3.} & $\begin{array}{l}\text { Pengajar yang memberikan pelatihan pra-OSN matematika dan } \\
\text { sains mampu memberikan motivasi, saran serta stategi untuk } \\
\text { mengikuti pelatihan pra-osn matematika dan sains }\end{array}$ & 59 & 60 & $98 \%$ \\
\hline & Persentase rata-rata untuk komponen pemapar materi & & & $98 \%$ \\
\hline
\end{tabular}

Dari hasil analisis angket $95 \%$ siswa setuju bahwa melalui pelatihan ini mereka lebih paham konsep IPA karena dibiasakan menggunakan problem solving. Hal ini juga sejalan dengan indikator pemapar materi yang meraih persentasi $98 \%$ di anggap menyajikan materi dan pembimbingan yang baik kepada siswa. Pada indikator motivasi menyatakan bahwa 93\% siswa termotivasi untuk belajar lebih giat karena merasa tertantang untuk mengikuti OSN setelah mengikuti pelatihan. Untuk indikator alokasi waktu, sekitar $70 \%$ responden menyatakan waktu yang diberikan efektif. Persentase alokasi waktu yang ditunjukkan tidak setinggi indikator yang lain karena beberapa siswa menyatakan 2 jam tiap pertemuan tersebut kurang cukup. Berdasarkan hasil evaluasi siswa dari tes dan angket setelah kegiatan pembekalan ini, terlihat bahwa PkM yang dilaksanakan sukses dan memberikan kontribusi yang baik bagi siswa sebagai bekal dalam mengikuti OSN 2020. 


\section{Kesimpulan}

Kegiatan pengabdian kepada masyarakat di SMP N 6 Tanjungpinang berjalan lancar. Siswa menjadi antusias dan tertantang untuk menghadapi OSN di tahun 2020. Pelatihan ini bisa dilaksanakan untuk sekolah lain yang akan mengikuti OSN, dengan menerapkan keterampilan abad 21 lainnya seperti berpikir kritis, kreatif dan kolaboratif. Adapun kelebihan dari kegiatan pengabdian ini adalah sebagai berikut:

1. Adanya pemahaman konsep IPA (fisika) yang lebih tinggi dengan menggunakan soal-soal problem solving berbasis representasi multimodus bagi siswa.

2. Adanya motivasi yang tinggi dari siswa untuk belajar mandiri dalam mempersiapkan OSN dan motivasi untuk terus menaklukan materi-materi IPA lainnya.

3. Pihak sekolah meminta pelatihan ini berkelanjutan dan siswa yang diikutkan bisa lebih dari 15 orang karena banyak siswa yang tertarik untuk mengikuti pelatihan.

Kekurangan-kekurangan yang terdapat dalam pelaksanaan PkM ini antara lain:

1. Alokasi waktu pelaksanaan PkM ini yang cukup singkat dan dilaksanakan pada waktu siang hari setelah pembelajaran sehingga fokus siswa tidak sebaik jika dilaksanakan pada pagi hari.

2. Anggota peserta PkM yang diikutkan terbatas karena keterbatasan dana pelaksanaan PkM yang berasal dari dana mandiri.

\section{Saran}

Saran yang dapat diberikan pada pelaksanaan kegiatan PkM serupa di masa yang akan datang adalah sebagai berikut:

1. Mengadakan kegiatan serupa dengan melibatkan siswa-siswa terpilih se-Tanjungpinang.

2. Mengadakan kegiatan pelatihan yang sama tetapi targetnya adalah guru-guru IPA yang menjadi pembina OSN se-Tanjungpinang.

3. Mengadakan kegiatan serupa tetapi menggunakan pendekatan keterampilan abad-21 lainnya seperti berpikir kritis, kreatif dan kolaboratif.

4. Menpertimbangkan agar kegiatan ini mendapatkan pendanaan yang cukup untuk mendapatkan hasil yang optimal.

\section{Ucapan Terima Kasih}

Tim PkM mengucapkan terima kasih kepada LP3M UMRAH yang telah memfasilitasi dan memberikan dukungan demi terlaksananya kegiatan PkM ini.Terima kasih juga kepada Prodi Pendidikan Matematika UMRAH yang telah memberikan dukungan hingga terlaksananya kegiatan ini. Selanjutnya, tim PkM mengucapkan terima kasih kepada kepala SMP N 4 Tanjungpinang yang telah memfasilitasi terlaksananya kegiatan pelatihan ini. Tidak lupa juga terima kasih kepada mahasiswa PPL UMRAH yang telah mengkoordinir keterlaksanaan kegiatan sehingga berjalan baik dan lancar.

\section{Referensi}

Ariyanti, G., Rahajeng, R., \& Sumadji, A. R. (2019). Pembinaan olimpiade sains melalui pemberdayaan klub matematika dan IPA bagi siswa SMP di Kota Madiun. Jurnal Abdimas BSI: Jurnal Pengabdian Kepada Masyarakat, 2(2), 350-358. https://doi.org/10.31294/jabdimas.v2i2.5667

BNSP. (2010). Pengembangan paradigma pendidikan nasional abad 21. Retrieved from http://www.bsnpindonesia.org/id/wp-content/uploads/2012/04/Laporan-BSNP-2010.pdf

BPK. (2010). Peraturan Pemerintah tentang Pengelolaan dan Penyelenggaraan Pendidikan. Retrieved from https://peraturan.bpk.go.id/Home/Details/5025/pp-no-17-tahun-2010

Ekmekci, A., \& Sahin, A. (2018). High school students' semantic networks of scientific method in an international science olympiad context. EURASIA Journal of mathematics, science, and technology 
education, $14(10)$.

Irwandani. (2014). Multi representasi sebagai alternatif pembelajaran dalam Fisika. Jurnal Ilmiah Pendidikan Fisika Al-BiRuNi, 3(1), 1-10.

Docktor, J. L., Strand, N. E., Mestre, J. P., Ross, B. H. (2015). Conceptual problem solving in high school physics. Physical Review Special Topics - Physics Education Research, 11(2), 1-13. https://doi.org/10.1103/PhysRevSTPER.11.020106

Kemdikbud. (2019). Petunjuk pelaksanaan OSN SMP 2019. Retrieved from http://repositori.kemdikbud.go.id/11132/1/Juklak_OSN_2019.pdf

Maries, A., \& Singh, C. (2013). Exploring one aspect of pedagogical content knowledge of teaching assistants using the test of understanding graphs in kinematics. Physical Review Special Topics - Physics Education Research, 9(2). https://doi.org/10.1103/PhysRevSTPER.9.020120

Marlina, R., Puspaningrum, H., \& Hamdani. (2017). Differentiation of test items between the high school biology olimpiad in North Kayong and the national science olimpiad. Jurnal Pendidikan IPA Indonesia, 6(2), 245-251. https://doi.org/10.15294/jpii.v6i2.10679

Muliani, F., Noviati, D., \& Fajriani. (2018). Pembinaan peningkatan mutu pendidikan bidang olimpiade sains bagi guru SD kota Langsa Provinsi Aceh. Jurnal ABDIMAS Unmer Malang, 3(2), 9-13.

Nguyen, D. H., Gire, E., \& Rebello, N. S. (2010). Facilitating students' problem solving across multiple representations in introductory mechanics. Proceedings of AIP Conference 1289 (pp. 45-48). https://doi.org/10.1063/1.3515244

Prain, V., \& Waldrip, B. (2006). An exploratory study of teachers' and students' use of multi-modal representations of concepts in primary science. International Journal of Science Education, 28(15), 1843-1866. https://doi.org/10.1080/09500690600718294

Rachmawati, D. O. (2014). Pembinaan Olimpiade Sains Nasional (OSN) fisika SMP di Kecamatan Mengwi. Proceedings of Seminar NAsional MIPA (pp. 231-238).

Steegh, A. M., Höffler, T. N., Keller, M. M., \& Parchmann, I. (2019). Gender differences in mathematics and science competitions: A systematic review. Journal of Research in Science Teaching, 56(10), 1431-1460. https://doi.org/10.1002/tea.21580

Van Heuvelen, A., \& Zou, X. (2001). Multiple representations of work-energy processes. American Journal of Physics, 69(2), 184-194. https://doi.org/10.1119/1.1286662

Wiyoko, T., \& Avana, N. (2019).Ppeningkatan kompetensi siswa melalui pembinaan olimpiade. Warta LPM: Media Informasi dan Komunikasi Hasil Pengabdian kepada Masyarakat, 22(2), 67-75. 